\title{
INFLUENCE OF ENZYME INDUCTION ON THE SLEEPING TIME OF RATS*
}

\author{
Michael T. Piel, M.D., J. Antonio Aldrete, M.D., And George Jones, M.D. $†$
}

IN A REVIEW of the current concepts of metabolism of anaesthetic agents by Greene, it is conspicuous that many of these drugs depend on the integrity of liver function for their detoxification. ${ }^{1}$ For this reason, multiple hepatic enzyme systems have been repeatedly studied with each agent as it is introduced into experimental and clinical practice.

Conney and his co-workers ${ }^{2-4}$ have shown that "pretreatment" of rats with phenobarbital shortened the sleeping time produced by thiopental, hexobarbital, and pentobarbital. Other anaesthetic drugs which have been studied include morphine, meperidine $\mathrm{HCl}$, urethane, codeine, gluthetimide, nitrous oxide, methoxyflurane, and carbromal.

By direct methods, a quantitative increase in the liver microsomal enzyme activity has been demonstrated to be the responsible accelerating factor of the drugs' disposition. ${ }^{3,5,6}$ Conversely, a prolonged effect can be attained by the previous administration of compounds that would have an inhibiting action on the same enzyme systems. ${ }^{7}$

This study was intended to determine whether similar stimulating and inhibiting mechanisms would influence the sleeping times of rats receiving more recently introduced anaesthetics such as gamma hydroxybutyrate, 2-orthochlorophenyl, 2-methylaminocyclohexanone (cI-581), and diazepam. To correlate our findings with previous reports, thiopental, pentobarbital, and the centrally acting muscle relaxant zoxazolamine were also tested.

\section{Materials and Methods}

Nineteen groups of ten rats each were divided into three allotments. Male albino Sprague-Dawley rats four to six weeks old and weighing 50 to 60 gm were used for all the studies. Intraperitoneal injections were given in the lower half of the abdomen in a dose corresponding to each animal's weight. The onset and duration of sleep were timed by the disappearance and return of the "righting reflex" (ability to turn spontaneously to the "on quarters" position when placed on the back). Animals that failed to show signs of anaesthesia were eliminated from the study.

The sleep-time periods in minutes were added and mean-times and standard deviations calculated. Statistical analysis of the results was conducted by the Student $t$-test.

'This study was supported by US Public Health Service grant FR 05357-08 to the University of Colorado Medical Center.

†Division of Anesthesiology, University of Colorado Medical Center, and the Veterans Administration Hospital, Denver, Colorado. 


\section{Control group}

Seven groups of ten rats each were injected intraperitoneally with the following solutions:

\begin{tabular}{lrc} 
& \multicolumn{2}{c}{$0.5 \mathrm{ml}$} \\
sodium chloride solution & $40 \mathrm{mg} / \mathrm{kg}$ \\
sodium thiopental & $25 \mathrm{mg} / \mathrm{kg}$ \\
sodium pentobarbital & $200 \mathrm{mg} / \mathrm{kg}$ \\
zoxazolamine & $15 \mathrm{mg} / \mathrm{kg}$ \\
diazepam & 30 & $\mathrm{mg} / \mathrm{kg}$ \\
Ketalar (cr-58I) & $150 \mathrm{mg} / \mathrm{kg}$
\end{tabular}

\section{Activation by enzyme induction}

Six groups of ten rats each received phenobarbital $(30 \mathrm{mg} / \mathrm{kg})$ injections intraperitoneally twice daily for four consecutive days; on the fifth day the rats were injected with the drugs mentioned above and the onset and sleep-time duration observed, as determined by the appearance of the "righting reflex."

\section{Inhibition by enzyme induction}

Six groups of ten rats each had $100 \mathrm{mg} / \mathrm{kg}$ beta-diethylaminoethyl diphenylpropylacetate (sKF 525-A) administered intraperitoneally one hour prior to the injections of the studied drugs. Their sleep-times were noted.

\section{RESULTS}

The rats which were treated with phenobarbital for four days prior to the administration of anaesthetics had a significantly shorter sleeping time than those that received no pretreatment (see Table I). In contrast the groups of rats that were treated with SKF 525-A one hour prior to the administration showed a significantly increased duration of sleep when compared with the control groups of animals (Table II). All these differences in duration of action, whether shortened or prolonged, were statistically significant when compared to the control (nontreated) groups of rats. Neither phenobarbital nor SKF 525-A pretreatment affected the time of onset of anaesthesia when compared with the control animals.

TABLE I

\begin{tabular}{lccc}
\hline \hline & \multicolumn{2}{c}{$\begin{array}{c}\text { Duration of sleep } \\
\text { in minutes and } \\
\text { standard deviation }\end{array}$} & \\
\cline { 2 - 3 } $\begin{array}{c}\text { Anaesthetic } \\
\text { agent }\end{array}$ & control & $\begin{array}{c}\text { phenobarbital } \\
\text { pretreated }\end{array}$ & Significance \\
\hline Pentobarbital & $89 \pm 18$ & $53 \pm 6$ & $p<0.05$ \\
Thiopental & $78 \pm 9$ & $52 \pm 5$ & $p<0.05$ \\
Zoxazolamine & $143 \pm 18$ & $93 \pm 9$ & $p<0.05$ \\
Cr-581 & $21 \pm 4$ & $8 \pm 1$ & $p<0.05$ \\
Diazepam & $47 \pm 3$ & $15 \pm 1$ & $p<0.05$ \\
GOH BA & $70 \pm 5$ & $42 \pm 4$ & $p<0.025$ \\
\hline
\end{tabular}


TABLE II

\begin{tabular}{lrcc}
\hline \hline & \multicolumn{1}{c}{$\begin{array}{c}\text { Duration of sleep } \\
\text { in minutes and } \\
\text { standard deviation }\end{array}$} & \\
\cline { 2 - 3 } $\begin{array}{l}\text { Anaesthetic } \\
\quad \text { agent }\end{array}$ & control & $\begin{array}{c}\text { SKF 525-A } \\
\text { pretreated }\end{array}$ & Significance \\
\hline $\begin{array}{l}\text { Pentobarbital } \\
\text { Thiopental }\end{array}$ & $89 \pm 18$ & $197 \pm 12$ & $p<0.025$ \\
Zoxazolamine & $78 \pm 9$ & $181 \pm 26$ & $p<0.05$ \\
CI-581 & $143 \pm 18$ & $280 \pm 10$ & $p<0.025$ \\
Diazepam & $21 \pm 4$ & $64 \pm 6$ & $p<0.025$ \\
GoH BA & $47 \pm 3$ & $86 \pm 7$ & $p<0.05$ \\
& $70 \pm 5$ & $103 \pm 12$ & $p<0.05$ \\
\hline
\end{tabular}

\section{Discussion}

The results of these experiments suggest that the duration of narcosis produced in rats can be altered, when activators or inhibitors of liver enzyme microsomal activity are previously administered.

\section{Antecedents}

It has been noted that treatment of rats and other animals with phenobarbital will cause an increased activity in a number of enzyme systems. ${ }^{2,3,6,8-13}$ Studies by Remmer ${ }^{14,15}$ and by Conney et al. ${ }^{4}$ suggested that tolerance and cross-tolerance to barbiturates might result from increased activity of the liver microsomal enzymes that metabolize these compounds. The proliferating effect of phenobarbital administration on the smooth endoplasmic reticulum (SER) of the mature hepatocyte is of importance, since the SER comprises the major portion of its structural microsomal segment. It has been suggested that the SER is the storage site of hepatic enzymes. ${ }^{17}$ Similarly, it was demonstrated in liver homogenates of animals pretreated with phenobarbital that microsomal enzyme activity was increased along with SER proliferation. The same treatment enhanced liver microsomal hydroxylating activity and was associated with a marked proliferation of the smooth endoplasmic reticulum. ${ }^{17}$

Several microsomal enzymes might respond differently to phenobarbital induction. Levels of the TPNH oxidizing flavo-enzyme and the CO-binding pigment p-450 can be increased parallel to the enhanced overall drug hydroxylating activity, whereas the amount of cytochrome $b_{5}$ and the nucleoside dephosphatase activity may display only a minor increase. In contrast, phenobarbital treatment lowers the activity of other enzymes such as glucose-6-phosphatase, ATPase and DPNH-cytochrome c reductase..$^{8,9}$

Many drugs, including a good number of the intravenous anaesthetics, are metabolized partially or in toto by conjugation with either glucuronic acid or sulfuric acid. One of the major detoxification pathways in the body is the following:

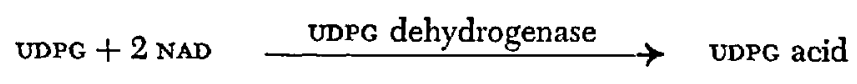

$$
\begin{aligned}
& \text { UDPGA + R-OH } \stackrel{\text { glucuronyl transferase }}{\longrightarrow} \mathrm{R} \text {-O-glucuronide }
\end{aligned}
$$


Zeidenberg et al. ${ }^{13,18}$ showed that phenobarbital treatment in rats produced an increased enzymatic activity of both UDPG dehydrogenase and glucuronyl transferase.

Newborn animals of a number of species, including man, are deficient in hepatic microsomal enzymes necessary for the metabolism of a variety of drugs and certain naturally occurring substrates such as bilirubin. ${ }^{19}$ This deficiency of microsomal drug-metabolizing enzymes in the newborm may play a role in the case of infants born to mothers that are heavily medicated with sedatives or analgesics during childbirth. It may also be of importance in the transient elevation of unconjugated bilirubin that occurs in the newborn. ${ }^{20}$ Pantuck et al. showed that meperidine $\mathrm{N}$-demethylating and pentobarbital hydroxylating enzyme activities were lower in newborn rat and rabbit livers than in older animals. ${ }^{11}$ In another study, the offspring of pregnant rats treated with $40 \mathrm{mg} / \mathrm{kg}$ of phenobarbital during the last five days of their pregnancy showed a significant increase in enzymatic activity, which approached the adult level.11 The metabolism of hexobarbital, aminopyrine and p-nitrobenzoic acid by the liver microsomes was found to be increased in offspring of female rabbits treated with phenobartital. ${ }^{21}$

In an extrapolation of this observation to clinical practice, Yaffe and coworkers ${ }^{22}$ treated a child with a congenital non-obstructive, non-haemolytic anaemia with resultant hyperbilirubinaemia with phenobarbital; a marked fall in serum bilirubin resulted. Also, the studies of Maurer et al. in pregnant women treated with $30-120 \mathrm{mg}$ of phenobarbital daily for the last five weeks of their pregnancy showed that all the pretreated newborns had significantly lower serum bilirubin levels than those of a control group. ${ }^{23}$

In actuality, it is thought that phenobarbital is capable of stimulating several liver enzyme systems, including that of glucuronide formation. Other compounds with the same activating effect are 3,4 benzpyrene, ${ }^{2} 3$ methylcholantrene, ${ }^{9,10}$ and DDT. ${ }^{2}$ Some drugs with narcotic action can also stimulate their own metabolism during chronic administration. 2,24

Other compounds can inhibit hepatic microsomal enzyme systems. Among these are ethionine, ${ }^{2}$ actinomycin $\mathbf{D}$, puromycin and SKF 525-A. ${ }^{7}$. This latter drug has been noted to cause a marked decrease in hepatic glycogen and inhibited the microsomal metabolism of hexobarbital, aminopyrine, and codeine for up to twenty-four hours. ${ }^{7}$ Conney and Burns ${ }^{5}$ showed that SKF 525-A inhibited such enzyme systems as $\mathrm{N}$-demethylation, side chain oxidation, deamination, hydroxylation, ether cleavage, nitro group reduction, and glucuronide formation. They postulated that the inhibitory effect of SKF 525-A on drug-metabolizing enzymes may account for the prolongation of barbiturate or zoxazolamine induced sleeping time in rats.

\section{Metabolic pathways of anaesthetics used}

From the above mentioned data, it can be surmised that phenobarbital pretreatment does indeed cause an increased rate of metabolism of some drugs. Contrarily, SKF 525-A causes a decreased metabolism. When these concepts were applied to the anaesthetic drugs tested in this study, these facts appeared to be consistent. 
Barbiturates. Three processes are responsible for the termination of the central depressant action of barbiturates: physical redistribution, metabolic degradation, and renal excretion. The principle site of most barbiturate biotransformation is the liver. Transformation results in more polar compounds which are more easily excreted by the kidney. This process is accomplished by oxidation of radicals at c5, N-dealkylation, desulfuration of the thiobarbiturates, and destruction of the barbituric ring. The major product is excreted in the form of glucuronide conjugate. ${ }^{1,25}$

Zoxazolamine. This compound is also nearly totally biotransformed before excretion. According to Conney et al. ${ }^{26}$ only 1 per cent of the total dose is excreted in the unchanged form. Two major products of zoxazolamine metabolism, which occurs in the liver, have been identified: chlorzoxazone, a hydroxyl group, and 6$\mathrm{OH}$-zoxazolamine. Approximately 1-2 per cent of the total dose is excreted as chlorzoxazone. But nearly 50 per cent of the 6-OH-zoxazolamine is excreted in the form of a glucuronide conjugate.

Ketalar ${ }^{\circledR}$. Chen et al. ${ }^{27}$ showed that the metabolism of CI-581 involves $\mathrm{N}$-dealkylation, which occurs in the liver. Moreover, Chang, Dill, and Glasko ${ }^{28}$ identified the two major breakdown products: a primary amine which is further degraded by oxidation to the cyclohexene derivative. Both are excreted in the form of a glucuronide conjugate.

Diazepam. This derivative of benzodiazapine is metabolized primarily in the liver. The major product of excretion is the glucuronide and/or sulfate conjugate of the $\mathrm{N}_{1}$-desmethyl- $\mathrm{C}_{3}$-hydroxy derivative. ${ }^{29}$

Gamma-hydroxybutyrate. The breakdown of this anaesthetic has not been entirely defined, but it is known that it undergoes transformation into gamma-butyro lactone. ${ }^{30}$ From here, the lactone enters the Krebs cycle, since radioactive $\mathrm{CO}_{2}$ has been detected in the expired air of rats receiving tagged gamma-hydroxybutyrate.

\section{Interpretation}

Considering that phenobarbital appears to increase and SKF 525-A to decrease the enzymatic activity in the microsomal segment of the hepatocyte, it is suggested that the prolonged and shortened sleeping times observed in the pretreated animals in contrast to the control (untreated) rats (Figs. 1 and 2) were due to the effect that phenobarbital and SKF 525-A exerted on the enzyme systems controlling the metabolism of these anaesthetic agents. Although many of the enzyme systems are activated, one common pathway exists in the metabolism of these drugs (with the remote but possible exception of gamma-hydroxybutyrate), the glucuronyl transferase system. One of the effects of phenobarbital pretreatment is to enhance the glucuronyl transferase system and, as a result, to prolong the action of the anaesthetics studied.

If extrapolation of these experimental studies is allowed, some cases of "tolerance" or "resistance" to some anaesthetic agents could be explained on the basis of possible enzyme induction. An opposite situation could be found in dealing with patients with severe liver dysfunction in whom enzymatic systems would be impaired; thus potentially these intravenous anaesthetic agents would have greater 


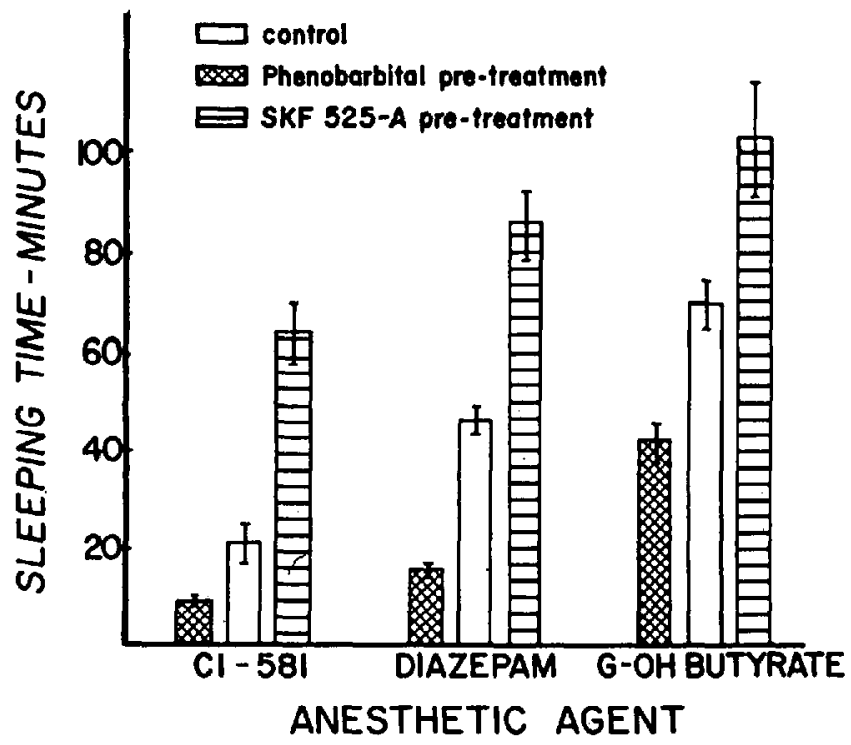

Figure 1

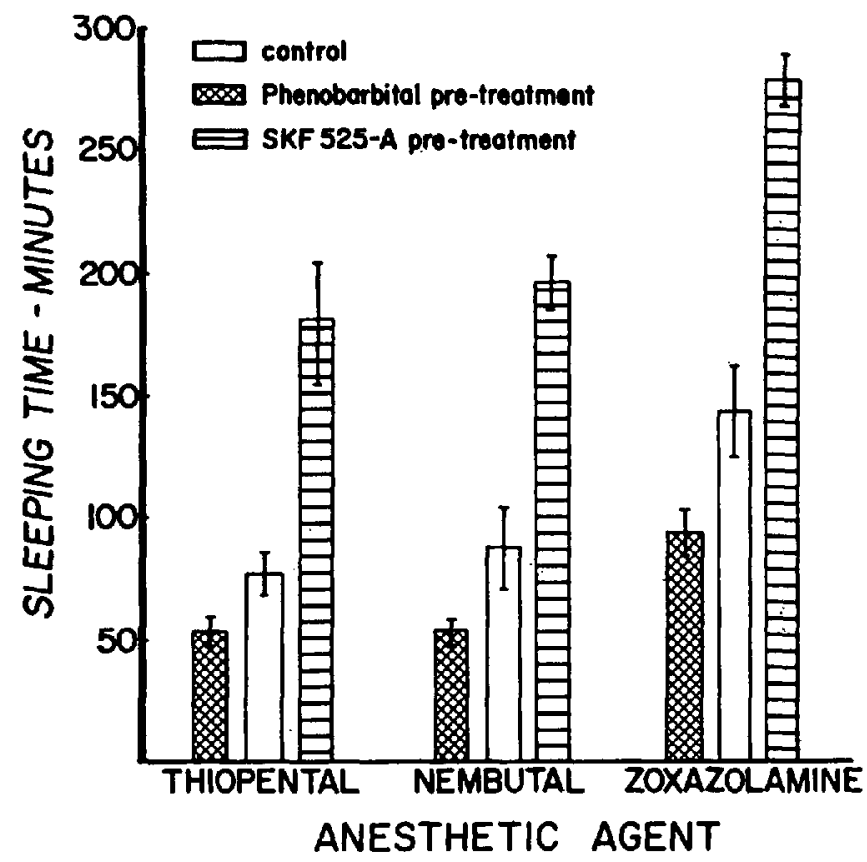

Figure 2 
and more protracted effect.,31-34 Undoubtedly more elaborate studies (with direct determination of enzyme activity) are necessary to arrive at more objective conclusions on this subject.

\section{SUMMary}

Hepatic microsomal enzyme systems can be activated by pretreatment with phenobarbital, other barbiturates, DDT, and many other drugs. Contrarily, another compound such as SKF 525-A, ethionine, and puromycin can inhibit the same enzymatic mechanisms.

The sleep-time periods of albino rats produced by pentobarbital, thiopental, zoxazolamine, CI-581, diazepam, and gamma-hydroxybutyrate were significantly shortened by previous administration of phenobarbital twice daily for four days. However, the duration of action of the same anaesthetics was significantly prolonged when the animals were "pretreated" by the administration of SKF 525-A, an inhibiter of liver microsomal enzymes.

\section{RÉSUMÉ}

Des groupes de dix rats chacun ont reçu en injections intrapéritonéales des médicaments employés en pratique anesthésique comme sédatifs ou comme agents anesthésiques par voie endoveineuse. Nous avons déterminé la durée du sommeil par la présence ou l'absence du "réflexe à se lever." Un certain nombre d'animaux ont été traités d'abord durant quatre jours par des injections, deux fois par jour, d'une quantité de phénobarbital $30 \mathrm{mg} / \mathrm{kg}$ et ce n'est que le cinquième jour que l'agent anesthésique a été injecté. Dans tous les groupes, nous avons observé une diminution importante de la durée des périodes de sommeil. Par contre, les rats qui avaient reçu $100 \mathrm{mg} / \mathrm{kg}$ de beta-diéthylaminoéthyl diphénylpropylacétate (SKF 525-A) ont connu une prolongation de leurs périodes de sommeil.

Un traitement préalable au phénobarbital et au SKF 525-A a démontré que ces médicaments pouvaient respectivement augmenter et diminuer l'activité des enzymes hépatiques microsomales, probablement par prolifération du réticulum lisse endoplasmique des hépatocytes. Les médicaments que nous avons étudies sont le pentobarbital, le thiopental, le Ketalar (CI-581), le diazepam, le gamma hydroxybutyrate et le myorésolutif zoxazolamine qui, jusqu'à un certain point, est métabolisé par le foie et partiellement éliminé comme glucuronides. Le glucuronyl transferase, une enzyme impliquée dans le dernier processus, peut être soit activée soit inhibée par un traitement au préalable au phénobarbital ou au SKF 525-A respectivement.

L'intéraction des médicaments, par effet sur les systèmes hépatiques d'enzyme microsomal peut être responsable de certains cas de "tolérance" ou de "sensibilite" à certains agents anesthésiques par voie endoveineuse.

\section{ACKNOWLEDGMENTS}

The SKF-525-A was provided for this study by Smith, Kline and French Laboratories, and the zoxazolamine was provided by McNeil Laboratories. Parke-Davis 
Co. provided the Ketalar, and Wyeth Laboratories provided the gamma-hydroxybutyrate.

\section{REFERENCES}

1. Greene, N. M. The Metabolism of Drugs Employed in Anesthesia. Anesthesiology. 29: 127,237 (1968).

2. Conney, A. H. Pharmacological Implications of Microsomal Enzyme Induction. Pharm. Rev. 19: 317 (1967).

3. Conney, A. H.; Davison, D.; Gastel, R.; \& BuRns, J. J. Adaptive Increase in DrugMetabolizing Enzymes Induced by Phenobarbital and Other Drugs. J. Pharm. Exper. Therap. 130: 1 (1960).

4. Connex, A. H.; Michaelson, I. A.; \& Burns, J. J. Stimulatory Effect of Chlorcyclizine on Barbiturate Metabolism. J. Pharm. Exper. Therap. 132: 202 (1961).

5. Conney, A. H. \& Burns, J. J. Factors Influencing Drug Metabolism. Adv. Pharm. 1: 31 (1962).

6. Fouts, J. R. Factors Affecting Hepatic Microsomal Enzyme Systems Involved in Drug Metabolism. Adv. Enz. Regulat. 1: 225 (1963).

7. Rogers, C. A. \& Fours, J. R. Some of the Interactions of SEF 525-A with Hepatic Microsomes. J. Pharm. Exper. Therap, 146: 286 (1964).

8. Gillette, J. R. Factors That Affect the Stimulation of Microsomal Drug Enzymes Induced by Foreign Compounds. Adv. Enz. Regulat. I: 215 (1963).

9. Gram, T. E.; Rogers, L. A.; \& Fouts, J. R. Effect of Pre-Treatment of Rabbits With Phenobarbital or 3-Methylcholanthrene on the Distribution of Drug-Metabolizing Enzyme Activity in Subfractions of Hepatic Microsomes. J. Pharm. Exper. Therap. 157: 435 (1967).

10. Kato, R. \& Takayanagh, M. Differences among the Action of Phenobarbital, Methylcholanthrene and Male Sex Hormone on Microsomal Drug-Metabolizing Enzyme Systems of Rat Liver. Jap. J. Pharm. 16: 380 (1966).

11. Pantuck, E.; Conney, A. H.; \& Kuntzman, R. Effect of Phenobarbital on the Metabolism of Pentobarbital and Meperidine in Fetal Rabbits and Rats. Biochem. Pharm. 17: 1441 (1968).

12. UehLehe, H. \& Greim, H. Stimulation of Kidney Microsomal Drug Metabolism by Phenobarbital. Naunyn. arch. pharm. exper. path. 259: 199 (1968).

13. Zemenderg, P.; OrRenius, S.; \& Ernster, L. Increase in Levels of Glucuronylating Enzymes and Associated Rise in Activities of Mitochondrial Oxidative Enzymes upon Phenobarbital Administration in the Rat. J. Cell. Biol. 32: 528 (1967).

14. Remmen, H. Der Beschleunigte Abbau von Pharmaka in den Lebermikrosomen unter dem Einfluss von Luminal, Naunyn. arch. exper. pathol. pharm. 235: 279 (1959).

15. Remmen, $H$. Die Beschleunigung der Evipanoxydation und der Demethylierung von Methylamino Antipyrin durch Barbiturate. Naunyn. arch, exper. pathol, pharm. 237: 256 (1959).

16. Orrenius, S. \& Ericsson, J. L. E. Enzyme-Membrane Relationship in Phenobarbital Induction of Synthesis of Drug Metabolizing Enzyme System and Proliferation of Endoplasmic Membranes. J. Cell. Biol. 28: 181 (1966).

17. Orrenius, S. \& Erucsson, J. L. E. On the Relationship of Liver Glucose-6-Phosphatase to the Proliferation of Endoplasmic Reticulum in Phenobarbital Induction. J. Cell. Biol. 32: 243 (1966).

18. Zemensere, P.; Orrenius, S.; \& Ernster, L. Enhancement of Glucuronylating Enzymes and Mitochondrial Oxidative Enzymes in Livers of Rats Treated with Phenobarbital. Trans. New York Acad. Sc. 29: 310 (1967).

19. Dutrom, G. J. Glucuronide Synthesis in Foetal Liver and Other Tissues. Biochem. J. $71: 141$ (1959).

20. Artas, I. M.; Gartner, L.; Furman, M.; \& Wolfson, E. Effect of Several Drugs and Chemicals on Hepatic Glucuronide Formation in Newborn Rats. Proc. Soc. Exper. Biol. Med. 112: 1037 (1963).

21. Hart, L. G.; Adamson, R. H.; Dixon, R. L.; \& Fours, J. R. Stimulation of Hepatic Microsomal Drug Metabolism in the Newborn and Fetal Rabbit. J. Pharm. Exper. Therap. 137: 103 (1962).

22. YafFeE, S. J.; LevY, G.; Matsuyawa, T.; \& Baliah, T. Enhancement of GlucuronideConjugating Capacity in a Hyperbilirubinemic Infant Due to Apparent Enzyme Induction by Phenobarbital. New England J. Med. 274: 1461 (1966). 
23. Maurer, H. M.; Wolff, J. A.; Poppers, P. J.; Finster, M.; Pantuck, E.; Kuntzman, R.; \& ConNeY, A. H. Reduction in Concentration of Total Serum-Bilirubin in Offspring of Women Treated with Phenobarbitone during Pregnancy. Lancet. 2: 122 (1968).

24. Axelrod, J. \& Inscoe, J. K. Glucuronide Formation of Narcotic Drugs in vitro and in vivo. Proc. Soc. Exper. Biol. Med. 103: 675 (1960).

25. Goodman, L. S. \& Gilman, A. The Pharmacological Basis of Therapeutics. 3rd ed., New York: Macmillan (1966).

26. Conney, A. H.; Trousof, N.; \& Burns, J. J. The Metabolic Fate of Zoxazolamine In Man. J. Pharm. Exper. Therap. 128: 333 (1960).

27. Chen, G.; Glazko, A. J.; Kaump, D. H. Ci-581: Laboratory Summary. Exper. Therap. Dept., Parke, Davis \& Co. (1958).

28. Chang, T.; Dill, W. A.; \& Glazko, A. J. Metabolic Disposition of 2-0-Chloro-2-Methylamino Cyclohexanone (CI-581) in Laboratory Animals and in Man. Fed. Proc. 24: 268 (1965).

29. Schwartz, M. A.; Koechlin, B. A.; Postma, E.; Palmer, S.; \& Krol, G. Metabolism of Diazepam in Rat, Dog, and Man. J. Pharm. Exper. Therap. 149: 423 (1965).

30. Roth, R.H. Preliminary Report on the Metabolism of Gamma-Butyrolactone and GammaHydroxy Butyric Acid. Biochem. Pharmacol, 14: 177 (1965).

31. Bourne, W. Anesthetics and Liver Function. Am. J. Surg. 34: 486 (1936).

32. Cameron, G. R. \& DeSaram, G. W. The Effect of Liver Damage on the Action of Some Barbiturates. J. Path. Bact. 48: 49 (1939).

33. Litrle, D. M. \& Wetstone, H. J. Anesthesia and the Liver. Anesthesiology. 25: 815 (1964).

34. WAkIM, K. B. Basic and Clinical Physiology of the Liver, Normal and Abnormal. Anesth. \& Anal. 44: 632 (1965). 